\title{
African Women Commuter Traders in Nairobi in the First Decade after World War 1: 1919-1929
}

\author{
Pamela Olivia Ngesa \\ Department of History and Archaeology \\ University of Nairobi, Kenya \\ pamela.ngesa@uonbi.ac.ke OR ngesap@yahoo.com
}

DOI: http://dx.doi.org/10.4314/tp.v6i1.6

Thought and Practice: A Journal of the Philosophical Association of Kenya (PAK)

New Series, Vol.6 No.1, June 2014, pp.63-80

thoughtandpractice@gmail.com

http://ajol.info/index.php/tp/index

ISSN: 2076-7714 


\begin{abstract}
This article investigates African women commuter trading activities in Nairobi in the first decade after World War One. Its findings derive mainly from a research project carried out in 1989-1996. The major source of data for the study was oral interviews with the women who traded in Nairobi during the years under study, as well as with eyewitnesses to their trading activities. Sampling of such respondents employed the purposive technique because of its ability to deal with the problem of an incomplete population frame by conveniently drawing the required study sample from available resources. The research drew other data from library and archival sources, especially to corroborate the oral evidence. However, this article utilises additional archival and library data to achieve greater comprehensiveness than was attained in the earlier version. The article therefore makes an important intellectual contribution to the ongoing debate on the social, political and economic role and impact of African women's economic activities such as commodity trade in African towns.
\end{abstract}

\title{
Key Words
}

Commuter traders, pre-colonial, colonial, money economy, socio-economic differentiation

\section{Introduction}

Studies of African women's participation in the economy of colonial Nairobi indicate that a major source of income for their survival was prostitution (Bujra 1975; White 1990). Nonetheless, Bujra (1975) and White (1990), the main proponents of this view, also point to petty vending as a peripheral activity to the sex trade. Even so, they leave a gap as to what extent trade in Nairobi was a means of livelihood for African women commuting from the surrounding areas. Robertson (1997) has only partially bridged this gap by trying to capture the vast content of the trading activities of both men and women in what she calls the Nairobi area (which is basically the whole of the former Central Province), and through a whole century from 1890-1990, she offers only a survey of the women's enterprise activities in urban Nairobi, and the post World War 1 decade is no exception. A clear understanding of 
what progress the itinerant women traders made, and the impact their trading activities had on their lives, the lives of their families and of other Kenyan peoples is lacking.

The objective of this article, therefore, is to provide a more detailed analysis of the role women commuter traders played in the mushrooming Nairobi commercial sector from 1919 to 1929. The article also attempts to underscore what transformations such enterprise operations bestowed on the lives of the women traders themselves, and on other sections of Kenyan society, especially in the urban areas. The main focus of this discussion is the women's sale of agricultural produce, which comprised the major items they exchanged in towns such as Nairobi during this period (Bujra 1975; White 1990). Nevertheless, the article also attempts to highlight other non-agricultural items women handled, sometimes as outgrowths of the trade in agricultural produce. "Commuter traders", in our context, refers to those women who did not live in Nairobi, but travelled there daily or occasionally to dispose their goods.

This article is largely the result of a research project carried out in 1989-1996 (Ngesa 1996). It relies heavily on the oral evidence of the women who traded during the period under study as well as that of eyewitnesses to the women's enterprise activities, mostly family members such as sons or daughters who worked closely with them. The research drew other data from library and archival sources, especially to corroborate the oral evidence. However, this article utilises additional archival and library data to achieve greater comprehensiveness than was attained in the earlier version.

The article argues that the trading activities of African women in Nairobi were, in part, a continuation of the pre-colonial trading networks that women from Central Kenya had developed over the years. It posits that the rise of Nairobi as a commercial centre introduced monetary exchange, encouraged male migrant labour, but denied women formal employment opportunities.

The article is divided into four main sections. The first section offers a survey of the commuter women traders in the pre-colonial site of present day Nairobi, as well as a review of the women's activities in early colonial Nairobi to the end of World War 1. This is followed by a section which examines the situation of the commuter women traders in the economically fluctuating climate of the post-World War I period up to 1922 . The third main 
section focuses on emerging trading trends occasioned by the rising economic prosperity and a continuing transformation in the lifestyles of women during the period 1923-1929. Our finding discussed in the final and concluding section is that except for a short-lived depression in the years 1920-1922, the period 1919-1929 witnessed a rise in the trading activities involving commuter women in Nairobi. Issues driving women to trade were many and complex, but included the introduction of the money economy, the neglect of women in the provision of economic opportunities, and the acquisition of new tastes.

\section{A Survey of the Women Trade in the Pre-colonial Nairobi Site and Early Colonial Nairobi up to the end of World War I}

The history of women commuter traders in present day Nairobi goes back to pre-colonial years. Research among both the Kikuyu and Kamba shows that women participated in both local and long distance trade. Kikuyu women of child bearing age traded in the local markets, where they sold various goods every four days or so (Muriuki 1974, 108; Robertson 1997, 66). The market participants, usually co-wives, organized themselves in order of seniority, and the goods of the senior most wife had to be sold out before the next in rank could dispose any of her commodities (Robertson1997, 66). However, while much of this trade took place among the Kikuyu themselves, part of it involved the exchange of goods between them and the Maasai, Kamba and Ogiek. ${ }^{1}$ One of the major market areas in this inter-ethnic exchange was a pathway which separated the four communities, and which, by means of some stepping stones, crossed the Nairobi River at the point where it flowed from the Kikuyu Forest Reserve into the Athi Plains (Hake 1977, 19). Along this local folkway, Kikuyu women brought vegetables, flour, grain and fruits which they exchanged for Maasai sheep, skins and hides. The Ogiek obtained stock and hides from the Kikuyu and Maasai in exchange for forest products and game trophies (Thomson 1968, 308; Hake 1977, 1). The Kamba mainly exchanged beads, brass, iron wire, salt and cowrie shells (obtained from the coast) for ivory, tobacco and livestock from the Maasai and Kikuyu (Muriuki 1974, 108). Occasionally, however, they also offered to their neighbours items such as poisons, medicines, chains, snuff boxes and bows and arrows in whose production they were specialized. The livestock that the Kikuyu and Kamba women obtained from this exchange was a measure of wealth that was

\footnotetext{
${ }^{1}$ The Kikuyu, Kamba, Maasai and Ogiek are Kenyan ethnic communities who lived in the pre-colonial site of Nairobi.
} 
not under their control: they surrendered it to their husbands or other male guardians (Robertson1997, 65-66).

The emergence of Nairobi was historical and geographical. Historically, it had been a depot for equipment for the construction of the Kenya Uganda Railway (KUR) in 1896. In 1899, the headquarters of the KUR was officially moved from Machakos to Nairobi. Nairobi accommodated Railway workers and a whole range of Railway followers, among them men and women who either sought work or food at the railway camps. ${ }^{2}$ This made Nairobi a regional commercial hub, and women from the areas neighbouring the town exploited the new opportunities at the headquarters of the Railway. As early as 1902, Kikuyu women from areas neighbouring the town exchanged vegetables at the Indian Bazaar and at an open air market connected to it $(\mathrm{MOH} / 6019,1902)$.

In the same year (1902), however, an outbreak of plague occurred in the Indian Bazaar, claiming between 50 and 60 lives. The deaths were blamed on conditions of African congestion and poor sanitation (MOH/6019, 1902, 3; CP/PC 1/8/1, 1899-1916). As a measure against a future plague outbreak, the market was separated from the Bazaar and relocated to the north side of Nairobi river in the present day Kariokor estate, as an African market to ensure that Africans provided the needs of the town but did not "transmit disease" (Onstad 1990, 49). The African market became a focal point in the continuing women's trade, especially for commuters bringing food from their farms for sale in Nairobi (Onstad 1990, 49).

However, up to 1923, African women commuter traders had the task of negotiating their way around regulations that were meant to prevent their entry into colonial Nairobi. From the perspective of colonial administrators and African males whose common interest was to domesticate African women, town life "ruined women's morals" (Kanogo 2005, 5). It became the norm to label as a prostitute any woman who travelled unaccompanied to Nairobi, whether to reside there or to exchange goods and return home. The colonial

\footnotetext{
${ }^{2}$ The decade of 1890-1900 was a period of natural disasters and social change in Kenya. At intermittent periods during the decade, outbreaks of livestock diseases decimated herds. In the final years of the 1890s, the long rains failed and a famine followed. Consequently, many people wandered about in search of food. The spread of smallpox, for years endemic to Kamba, Kikuyu, Meru and Embu communities, also led some people to migrate to escape disease. Many of those uprooted by the misfortunes followed the Railway in search of work and food (see White, Luise. 1990. The Comforts of Home: Prostitution in Colonial Nairobi. Chicago: The University of Chicago Press.
} 
administration in collaboration with rural patriarchs enacted legislations prohibiting women from travelling to the Municipality even to sell produce, as this "would lead to prostitution and disease" (Kanogo 2005,7). Among these laws was the Vagrancy Ordinance first passed in 1902, to control the influx of Africans generally in to the town. However, as the years went by, the Nairobi colonial authorities realized that availability of male surplus labour encouraged very low wages, and the vagrancy law was applied more strictly on women than men (Hake 1977, 34-37).

A more specific measure to control women was the Nairobi Township By-Laws first enacted in 1903 and revised from time to time, by which native girls under the age of 18years were prohibited from living in the town, unless married and living with a husband, or under the guardianship of a responsible male, or in the service of a reputable employer (AG/5/468, 1918). However, driven by the desire to satisfy new tastes, especially for the imported western goods, women disobeyed these regulations, despite the risk of being branded prostitutes, or even being arrested on grounds of prostitution. By defying the By-Laws, these women were able to ferry their goods to Nairobi for sale. Thus, in spite of the attempt to restrict women's movement into towns such as Nairobi, the contradictions of colonialism caused the social disequilibrium that precipitated a transformation in the women's lives, and consequently necessitated their entry into the prohibited spaces (Kanogo 2005,7). Women's travel to distant places on trading missions, or to seek wage employment or opportunities for residence in faraway lands such as Nairobi, were evidence of the unfolding changes.

Some of the women wished to buy dresses and other goods associated with Western modernity so as to look like European women, but their husbands, although engaged in wage labour, for instance on the Railway, were unable to fulfil this desire. The women understood that their husbands' low wages, that did not even meet the men's own needs, would be even less able to satisfy the women's craving for trappings of Western modernity. The poor wages to which the women referred in interviews is corroborated by data that point to men's frequent visits to their rural ancestral homes to collect food produced on the family land to supplement their subsistence. Alternatively, a wife often carried foodstuff from the family land holding to her husband working as far as fifty miles or more away from home (Leys 1924, 307). 
An interesting phenomenon in this early period of colonialism was that women wearing European dress were considered to be prostitutes, which might partly explain why some husbands declined their wives' requests for European dress (Kanogo 2005, 7). However, owing to their persistence, some women obtained their spouses' permission to exchange a portion of the family land produce to meet some of their personal needs. Around 1908, one of these women carried her first load of bananas and sweet potatoes from her land in Gikambura, Kikuyu, to sell in Nairobi. Another one from Machakos had been forced out of marriage by the community's negative attitude towards her childlessness: in her desire for European linen, blankets and farm implements, she obtained ghee from her mother to commence her ghee trade in the Nairobi Municipality.

Included among the pioneer women traders were some of the earliest hawkers in Nairobi. As early as 1903, the Nairobi colonial town had identified a number of vegetable sellers operating illegally in the Jeevanjee market area within the town centre. By the township rules of 1915-16, the vending of goods anywhere in the centre of town was prohibited except with a permit which was to be obtained on the payment of a fee (AG 5/330, 1903). However, the women who came to hawk in Nairobi were unaware of these regulations. Besides, the cost of the permit was prohibitive for Africans, not just for women, but for men as well. In effect, African itinerant trading activities in Nairobi, for both men and women, were illegal, but in spite of police harassment, the traders were not deterred (AG 5/330).

Some of the illegal female hawkers were driven to engage in trade by great challenges, chief among which was the fact that at certain points in their lives they became heads of their households following either the death or disappearance of their husbands due to the then ongoing conscription into the military. They therefore desperately needed to provide for their children, and hawking was the only available avenue for achieving this goal. Some reared and sold chickens, while others hawked eggs to the affluent in European suburbs in Nairobi. Such commodities were exchanged for clothes or foodstuff such as tea and rice. Thus right from the early years of colonialism, most women who commuted to Nairobi to trade were in adverse circumstances, and hence in dire need of financial independence. Apart from meeting their own needs through trade, they also played a crucial role in meeting the demands of the town residents. 


\section{Commuter Women Traders in the Immediate Post World War I Economic Fluctuations: 1919-1922}

The first two years after World War I witnessed an increase in the population of all racesEuropeans, Asians and Africans - in Nairobi (Parker 1949, I-III). Part of this population consisted of demobilized askaris (soldiers) and members of the Carrier Corps, who brought with them earnings from war services rendered abroad. Such earnings were in turn used to buy local goods and services, as well as to pay for labour needs (Leys 1924, 161; Wrigley 1965, 234; Hake 1977, 39). There was also a group of Africans, most of whom were male immigrants seeking wage employment in the town. Such immigrants had been forced out of the reserves by the prevailing desperate situation caused by the continuing consequences of war, famine and epidemics (Maxon 1989, 72; Wrigley 1965, 255). Two other events facilitated the migration: the introduction of a system of labour registration in 1918, and the introduction of a tax system in the form of poll and hut taxes. These two made it difficult for men to avoid wage labour (Clayton and Savage 1974, 144; Leys 1924, 195).

Throughout the 1920s, Nairobi employment paid better wages than agricultural labour. One indicator of this is the fact that in the 1920s a large number of Africans sought work in the town, leading to an oversupply of labour; and many remained unemployed at a time when settler farms experienced a constant shortage of labour (Van Zwanenberg 1972, 179-180). The tendency of Nairobi to attract labour may also be attributed to its wage sector's relative freedom from the disciplinary abuses characteristic of agricultural work, where many employers took advantage of the kipande ${ }^{3}$ to persecute their employees (Van Zwanenberg 1972, 179-180; Clayton and Savage 1974, 132-133). Thus from a total population of 20,000 in Nairobi in 1912, only two years before the onset of World War I, the number had risen to about 23,000 by the end of 1920 (Hake 1977, 38-40,43; Parker 1949, Appendix 1). This increase in population led to further demand for goods, so that Nairobi enjoyed a trading boom leading to the flourishing of the commuter traders.

Furthermore, for women commuter traders, exchanging goods in Nairobi remained a major means to acquire cash to satisfy new tastes for imported goods and to invest. Some long serving commuter traders sustained the trade in the goods they had handled from the war years such as bananas and sweet potatoes in the African market. They were able to raise further cash savings with which they accumulated additional livestock. In trade, women found a means to empower themselves and to perform new roles in a system which frequently removed the husband/father/ breadwinner from the family setting. Until the outbreak of World War I, many had depended on their husbands, who periodically worked on

3 This was an identification pass system established in 1918 to control the movement of African labourers and to prevent them from deserting their employers. The kipande was normally a certificate in which the owner's previous and current labour history was entered, including the nature of employment, date of engagement, length of contact and wages paid (see Kanogo, Tabitha. 1987. Squatters and the Roots of Mau Mau, 1905-1963. Nairobi: Heinemann. 
settler farms to meet the financial requirements of their families. When the men were recruited into war service, the burden of providing for their families fell on their wives. They began selling vegetables in Nairobi's African market, where their main customers were Indian grocers who re-sold the goods in their shops in the town centre. After the war, some of these women entered into agreements with some of their Indian clientele to supply the vegetables directly to their shops along River Road. This involved carrying heavier cargo than they had done individually, so they turned to neighbours for assistance. They did not compensate this support in cash, but offered their assistants a good meal once they returned home. Thus Kanogo $(1989,115)$ correctly notes that the Kikuyu and Kamba supplied foodstuff in Nairobi in the 1920s, and that this was sometimes done through Indian intermediaries. By the onset of the localised post World War 1 depression at the end of 1920 (more below), some of these women commuter traders had also joined the list of cash savers.

Meanwhile, Ukambani, one of the areas neighbouring Nairobi, was hit by a serious food shortage after the war, and many men and women were forced to migrate elsewhere in search of food (Wrigley 1965, 255). Some of the women affected by this adversity ended up as traders. By the 1920s a small number of women were in domestic employment (Clayton and Savage 1974, 124; Stichter 1975, 10), and in their midst were the women migrants from parts of Ukambani, who moved to Machakos, where they worked as ayas (house helps) in Indian households. Some of these women had learned trade from their mothers, some of whom had grown tobacco and exchanged snuff locally in Ukambani. Having saved a little money from their wages, such women began to trade in snuff. Initially, they acquired the goods from tobacco growers in Kitui and marketed them in Nairobi's Pangani location. Their customers were mainly Kikuyu and Kamba men with whom they readily communicated in the mother tongue.

However, the distance of over 110 Kilometres between Nairobi and Kitui, in an era when the automobile was still an extremely rare means of transport, made the women's commuter trade difficult. For this reason, they traded in Nairobi for only a few days a month. Nonetheless, by 1923, thanks to their thriftiness, some had made sufficient savings to rent houses in Pumwani, and to establish themselves as middle women traders in the sale of snuff. They now obtained the goods from up-country commuters selling the snuff outside the African market, and in turn sold them to African snuff smokers in Pumwani where they lived. Their net profits, which averaged 10 to 15 Florins 4 a month, enabled them to provide for their basic needs and

\footnotetext{
${ }^{4}$ In the early years of the $20^{\text {th }}$ century, the currency in British East Africa was the Rupee, worth 1s. $4 \mathrm{~d}$. Sterling, at the rate of Rs 15 to the Sterling Pound. In 1921-1922,the Rupee became the Florin, at 10 Florins to the Sterling Pound. The unit was later changed to the East African Shilling, which was tied to the Sterling on the
} 


\section{Pamela Olivia Ngesa}

to increase their sales. Nevertheless, unlike other women who accumulated cash, these women were basically subsistence traders, as life in Nairobi meant purchasing all basic needs. The women's account echoes Berida Ndambuki's story as told by her and Robertson in later years that "we [women traders] only come here [to Nairobi] to struggle" (Ndambuki and Robertson 2000).

Generally, the women attributed their success in trade to their own hard work and keenness in identifying opportunities under some very difficult circumstances. Some of these commuter traders were widows, others single mothers, while others' husbands were away in the military. The ability to make independent decisions was crucial because husbands were perceived to be patronizing. Independent decisions were required not simply concerning what to trade in, where to trade and how to go about it, but also how the proceeds from the trade were to be spent.

From the end of 1920, Kenya was hit by an economic slump. As a result, the economic vitality that had characterized Nairobi's war years slackened. By March 1921, the provincial administration in the then Ukamba Province got concerned at how “... money was extremely scarce, trade was abnormally bad, and there was practically no market for East African produce" (Kenya National Archives 4/2/2, 1920-21, 7). To make matters worse, this economic hardship affected the Kenya colony such that there were general wage reductions in the entire colony, besides the demand for African labour declining. The prices of most African commodities fell below previous levels (Kenya National Archives 4/2/2, 1920-21, 7). This was devastating for the African women commuter traders.

Some women commuter traders were however determined to weather the storm and carry on with their trading activities. Many adopted new strategies. Unlike their counterpart middle women traders who were squeezed out of trade because of losses or poor profits, the innovative women went out of the market to search for buyers in Indian and African residential areas. As they lugged their wares along, they loudly notified prospective buyers by their shout of their presence and their desire to satisfy their clients' needs. African and Indian households were in need of various products such as mboga (vegetables). Thus for the 
housewives, instead of going to the market, the market would come to them, in the comfort of their homes. This Mama Mboga (mother of vegetables) phenomenon still dominates Indian neighbourhoods in Nairobi today. It is this aggressive selling strategy that enabled some of the commuter women to make profits enough to cater for their financial needs - earnings that were at times far higher than those of many African male labourers (Parker 1949, 83). This enabled the commuter women live a more comfortable life, such as enjoying the luxury of having tea and bread for breakfast while maintaining their children in school at a time when many other children were forced to drop out for lack of both food and school fees. For these women, innovativeness became the key to success.

\section{Economic Prosperity and Changing Lifestyles Facilitate Thriving Women Commuter Activities in Wholesaling and Hawking: 1923-1929}

The period 1923-1929 were years of economic revival for the Kenya colony. African agriculture throughout the country expanded buoyantly from 1922 to 1925 due to good weather and rising prices (Stichter 1982, 75-77). This was particularly so in many parts of Central Kenya, the main hinterland of Nairobi, where notable increases in agricultural production occurred under the stimulus of the construction of the Thika-Nyeri railway line (Stichter 1982, 75-77). The boom conditions aroused labour demands both in the countryside and in the towns. In Nairobi it stimulated the construction industry, which between 1925 and 1926 saw the erection of water supply and sewerage works for new housing development, and an extensive programme of road works (Hake 1977, 45). In 1929, the Nairobi Municipality completed the construction of its first African housing estate at Quarry Road, present day Kariakor on the site where the Carrier Corps camp stood (Hake 1977, 45). On its part, the Government completed the first phase of Starehe estate for its own employees (Hake 1977, 45). The year 1929 also witnessed the beginning of construction work on maternity homes for African and Asian communities, while new premises for the Mathari Mental Hospital were built between 1929 and 1930 (Hake 1977, 45).

These developments attracted a fresh wave of African immigrants into Nairobi. In 1923, the African population in Nairobi was approximately 12,000 (Parker 1949, I-III). By 1927, the figure had more than doubled to 25,000, and not less than 20,000 were male employees (Stichter 1982, 43-44). By 1929, the total African population in Nairobi was estimated at 


\section{Pamela Olivia Ngesa}

32,000 , and many became employed in the civil works being undertaken by the government (Hake 1977, 44-45). This growing population, coupled with the increased number of wage earners, stimulated a rising demand for commodities accompanied by buoyant prices. The situation proved favourable to the robust crop yields, notably maize, beans, potatoes and vegetables. In the African land units surrounding the town, owing to favourable weather and the subsequent glut in produce, goods were cheaper (Maxon 1989, 93-94; White 1990, 54; Kitching 1980, 38-39, 46). This period also witnessed the creation of official rural produce exchange markets, with clearly identified market days. This made the itinerant traders acquire merchandise for sale in Nairobi more easily than before.

Meanwhile, the continuing entrenchment of the money economy and missionary education catalysed a transformation in the women's lives. In parts of Ukamba Province, Africans, both men and women, were reported to be living in brick houses and had wooden beds and mattresses, pictures, cupboards, cutlery, bibles and other books and leather bags for travel (Kenya National Archives, Memorandum of Native Progress 1927, 3). The changes in dress were more radical, as European employers, especially missionaries, insisted on having "welldressed" employees. Missionaries also induced Christian converts to abandon traditional attire (Kenya National Archives Memorandum of Native Progress 1927, 4-7). By 1927, African lifestyles had changed so much that Edward Denham, the then Colonial Secretary, noted:

The demand for every kind of European clothing can not at present be met. The sales of second hand European clothing have become weekly fares in Nairobi at which Natives congregate in very large numbers. One auctioneer of such clothes states that in 1925 he sold approximately 4000 shillings worth of clothing, and in 1927 the sales amounted to about 6000 shillings. Kiambu and Dagoretti Indian shopkeepers report increases in sales in the last two years of 50 per cent in European clothing ..., 75 per cent in coloured handkerchiefs and an approximate increase in sales of clothing in four years of 80 per cent ... (Kenya National Archives Memorandum of Native Progress 1927, 8; See also Kenya National Archives PC/CP 4/1/2 1920-1932).

In response to the changing lifestyle needs and the economic prosperity, women from areas neighbouring Nairobi intensified their trading activities in the town. They came from Kiambu, Murang'a and Machakos to exchange their wares in the metropolis (Maxon 1989, 96-97). 
However, the use of traditional means of transport, especially human porterage and the pushcart, persisted as the major avenues of getting goods to town. In spite of the arrival of the automobile in Nairobi in 1902, up to the 1920s its use by women traders remained uncommon. One reason for this was that until then, an aura of mystery was built around the automobile, with negative myths built around it, hence distrusted by a section of Africans who used it only as a last resort (Kenya National Archives Memorandum of Native Progress 1927, 10). In addition, many women traders thought that boarding a motorised vehicle was a luxury that would divert money that could be used to purchase more deserving goods and services for African families. Moreover, although as the 1920s wore on a few Africans, women included, gradually became familiar with the motor vehicle, roads in the rural areas were few and poor, and motorised vehicular service extremely rare and low. For example, by 1927, there were only 81 motor buses connecting Nairobi to various destinations in the reserves (Kenya National Archives Memorandum of Native Progress 1927, 10). Thus women traders continued to walk to Nairobi, or to use bicycles or ox-drawn transport to ferry their merchandise to the municipality.

Meanwhile, some political developments in the 1920s encouraged the entry of a new set of commuter women into hawking in Nairobi. The release of the 1923 Devonshire White Paper, which declared the paramountcy of African interests, was one of these. In reality, this was a scheme by British colonialists to counteract Asian agitation for equal sharing of power in the colony (Smart 1950, 48; Onstad 1990, 122). Nonetheless, the Nairobi Municipal authorities, ostensibly in the spirit of the White Paper, passed a new by-law in 1923, allowing Africans to sell their own produce such as foods, charcoal and snuff without a hawker's licence (Kenya National Archives AG/ 5/470; 28/6/1933). The women commuter traders, being largely illiterate, were not aware of the new by-law. However, they came to realize that African vendors in the town were no longer arrested as vagrants or trespassers as had been the case before. Some commuter traders took advantage of the situation to hawk commodities in various parts of Nairobi. Among them were those who had for some years sold vegetables to Indian retail shop owners on River Road. However, these commuter women traders did not see the need for banking facilities, and hence hid their moneys in roofs of houses. Oblivious of the changes in currency, some of these women lost their savings. Nonetheless, some of them were able to re-launch their trade using their own farm produce, and operated as itinerant vendors in the same area of River Road where they had been wholesalers to Indian grocery owners, but with new customers - the Asian housewives - who by heeding the call of 


\section{Pamela Olivia Ngesa}

the Mama Mboga ${ }^{5}$ came to buy the goods. With the new policies which more or less granted Africans the freedom to conduct itinerant trade in Nairobi, there was a significant increase in the number of hawkers. Besieged by competition, upward mobility from hawking was difficult, and most of the women remained subsistence vendors. By the close of the 1920s, there was a clear differentiation between women commuter traders in Nairobi: the more innovative ones, especially the wholesalers, had set themselves apart as achievers of vertical mobility, while others, notably hawkers, simply struggled to subsist.

\section{Conclusion}

In this article, an attempt has been made to demonstrate that the period 1919-1929 saw an increase in the trading activities of women commuting to Nairobi from neighbouring areas. As more of them sought an income to purchase western goods for which they developed mounting appetite, they trooped to Nairobi to exchange local goods for cash. The favourable trading returns in Nairobi, compared with the outlying rural areas, made it a more attractive commercial centre. Our findings are that there was a conspiracy by African males and the colonizers to keep women out of the Nairobi commerce. These women commuter traders responded by forging innovative avenues to ensure their access to commercial activities. However, the persistence of the use of traditional means of transport to deliver goods to the town constrained the women's capacity to exhaust the demand for their wares. This notwithstanding, the women traders became an indispensable part of the distribution chain of the agricultural products that fed Nairobi cheaply, thereby supplementing the low waged labour system.

The main means of exchange for the women traders was minted currency, which enabled them to purchase western goods that brought remarkable changes to their lifestyles. By 1929, they had established sustainable livelihoods despite the fact that they continued to operate on the margins of the Nairobi economy. Some of these women commuter traders had accumulated profits, which they invested in property such as livestock. Others had diversified their enterprises by operating shops alongside their hawking activities. They became crucial in refashioning consumption patterns by distributing goods and services to the Nairobi population and their rural village communities. Another group of traders invested in social

\footnotetext{
${ }^{5}$ Kiswahili phrase, Literally "Vegetable mother".
} 
progress such as children's education, as well as improving their own living standards through the provision of better houses and other trappings of Western modernity. As some women became employers of labour, the benefits of their returns in trade trickled down to other members of society, leading to further lifestyle changes. The women traders were therefore important agents in the whole imperial scheme of ensuring availability of cheap urban labour and markets for British manufactured goods.

The article has presented three major arguments:

(1) Although the commuter women trade was a continuation of the pre-colonial trading networks of Central Kenya women, the growing Nairobi commerce and the contradictions of the colonial economy that introduced monetary exchange but denied women employment opportunities, facilitated the commuter women trade in Nairobi.

(2) The women's trade doubled up as their source of livelihood and a resource through which Nairobi African migrant labour was cheaply fed.

(3) The trade by these women was a means through which western goods were redistributed and popularized in Nairobi's peri-urban areas.

Thus this article unearths the little known history of African women commuter traders in Nairobi in the period 1919-1929. Their activities provide a window through which to partially understand how colonialism affected women within the areas neighbouring towns such as Nairobi in the 1920s, and how the women responded to this. By examining the way in which these women designed innovative trading strategies, we get a glimpse of colonialism's changing character during the period under study, especially in as far as economic policies were concerned. 


\section{References}

\section{Books, Journal Articles and Unpublished Theses}

Bujra, Janet M. 1975. "Women Entrepreneurs in Early Nairobi". Canadian Journal of African Studies, Vol.IX No.2, pp.213-234.

Clayton, Antony and Donald Savage. 1974. Government and Labour in Kenya, 1895-1963. London: Frank Cass.

Gray, Richard and David Birmingham. eds. 1979. Pre-colonial African Trade: Essays on Trade in Central and Eastern Africa Before 1900. London: Oxford University Press.

Hake, Andrew. 1977. African Metropolis: Nairobi's Self-Help City. London: Sussex University Press.

Harlow, V. and E.M. Chilver. eds. 1965. History of Africa Vol. II. Oxford: The Clarendon Press.

Kanogo, Tabitha. 1987. Squatters and the Roots of Mau Mau, 1905-1963. Nairobi: Heinemann.

--. 1989. “Kenya and the Depression, 1929-1939”. In Ochieng, William R. ed. 1989, pp.112143.

--. 2005. African Womanhood in Colonial Kenya, 1900-1950. Nairobi: EAEP.

Kershaw, G. 1975-76. "The Changing Roles of Men and Women in the Kikuyu Family by Socioeconomic Strata". Rural Africana,Vol.29, pp.173-194.

Kitching, Gavin. 1980. Class and Economic Change in Kenya: The Making of an African Petit Bourgeoisie, 1905-1970. New Haven: Yale University Press.

Lamphear, John. 1979. "The Kamba and the Northern Mrima Coast”. In Gray, Richard and David Birmingham eds. 1979, pp.81-87.

Leys, Norman. 1924. Kenya. London: Frank Cass.

Maxon, Robert. 1989. “The Years of Revolutionary Advance 1920-1929”. In Ochieng, William R. ed. 1989, pp.71-111.

Muriuki, Godfrey. 1974. A History of the Kikuyu, 1500-1900. Nairobi: Oxford University Press.

Ndambuki, Berida and Claire C. Robertson. 2000. "We Only Come Here to Struggle”, Stories from Berida's Life. Bloomington: Indiana University Press.

Ngesa, Pamela O. 1996. "A History of African Women Traders in Nairobi, 1899-1952". Unpublished M.A. thesis at the University of Nairobi. 
Ochieng, William R. ed. 1989. A Modern History of Kenya, 1895-1980. Nairobi: Evans Brothers.

Onstad, Eric. 1990. "Street Life: A History of Nairobi’s Petty Traders and Their Organizations, 1899-1975". Unpublished M.A. thesis at the University of Nairobi.

Parker, Mary. 1949. "Political and Social Aspects of the Development of Municipal Government in Kenya with Special Reference to Nairobi”. Unpublished Ph.D. thesis at the University of London.

Robertson, Claire. 1997. Trouble Showed the Way: Women, Men and Trade in the Nairobi Area, 1890-1900. Bloomington: Indiana University Press.

Smart, James. 1950. Nairobi: A Jubilee History, 1900-1950. Nairobi: The East African Standard.

Stichter, Sharon. 1975. "Women and the Labour Force in Colonial Kenya,1895-1964". Paper presented at the 18th Annual Meeting of the African Studies Association, San Francisco, October 29 1975, pp.10-12.

--. 1982. Migrant Labour in Kenya, Capitalism and African Response, 1895-1975. Harlow: Longman.

Thomson, Joseph. 1968. Through Masailand, A Journey of Exploration Among the Snowclad Volcanic Mountains and Strange Tribes of Eastern Equatorial Africa. London: Frank Cass.

Van Zwanenberg, Roger. 1972. "History and Theory of Urban Poverty in Nairobi: The Problem of Slum Development". Journal of Eastern Africa Research and Development, Vol.2 No.2, pp.165-203.

Von Hohnel, Ludwig. 1894. Discovery of Lakes Rudolf and Stefanie, A Narrative of Count Teleki's Exploring and Hunting Expeditions in Eastern Equatorial Africa in 1887 and 1888, Vol.I. Nancy Bill trans. London: Frank Cass.

White, Luise. 1990. The Comforts of Home: Prostitution in Colonial Nairobi. Chicago: The University of Chicago Press.

Wrigley, C.C. 1965. "Kenya: The Patterns of Economic Life, 1902-1945”. In Harlow, V. and E.M. Chilver eds. 1965, pp.209-264.

\section{Kenya Colony and Protectorate Documents at the Kenya National Archives}

Memorandum of Native Progress, 1927.

\section{Agriculture Department Files}

Annual Reports 1923-1925. 


\section{Office of the Attorney General Files}

The African Township Ordinance 1903: Reprinted in the Nairobi Township Ordinance Rules General, 1915-1916, AG5/330.

Nairobi Township: Native Pass and Service Rules, 1918, AG/468.

Licencing of Native Hawkers By-Law, 1923, AG 5/470.

\section{Provincial Files}

Kikuyu Province Annual Reports, 1920-1932, PC/CP 4/1/2.

Ukamba Province Annual Reports, 1906-1915, PC/CP 4/2/1.

Ukamba Province Annual Reports, 1915-1924, PC/CP 4/2/2.

Ukamba Province Annual Reports, 1925-1932, PC/CP 4/2/3.

\section{Ministry of Health Files}

MOH 1/5999, 1902.

MOH 1/6019, 1902.

MOH 1/1660, 1914.

\section{Municipal Council of Nairobi Files}

File 4/68, Markets and Marketing General, Market Rules 1937.

History of Nairobi File (Undated), 2/14/103.

Political Record Book, Nairobi District, 1899-1915, PC/CP 1/8/1. 